\title{
Relationships between overstory and understory structure and diversity in semi-natural mixed floodplain forests at Bosco Fontana (Italy)
}

\author{
Francesco Chianucci ${ }^{(1)}$, Emma \\ Minari ${ }^{(2)}$, Most Jannatul \\ Fardusi ${ }^{(1)}$, Paolo Merlini ${ }^{(1)}$, \\ Andrea Cutini ${ }^{(1)}$, Piermaria \\ Corona ${ }^{(1)}$, Franco Mason ${ }^{(3)}$
}

\begin{abstract}
The "Bosco Fontana" natural reserve includes the last remaining mixed floodplain forest in northern Italy and one of the most endangered ecosystems in Europe. Its effective management is hindered by the complexity of interactions of mixed-tree species and the influence of environmental factors on understory plant diversity. In this study we analyzed the patterns of natural evolution in semi-natural floodplain forest stands at Bosco Fontana with the aim of better understanding its current natural processes and dynamics. Stand structure, taxonomic and functional diversity, species composition, and leaf area index (LAI) of overstory and understory layers were surveyed in permanent plots over two inventory years $(1995,2005)$. The influence of environmental factors on understory plant diversity was assessed using Ellenberg's indices for light, soil moisture, soil nutrient and soil reaction. Results indicated that overstory species composition varies according to the soil moisture, with hornbeam prevailing in xeric sites and deciduous oak species in mesic sites. Xeric sites showed high functional dispersion in both drought and shade tolerant traits, while it was significantly lower in both overstory and understory in the moist site. Functional dispersion of drought tolerance in the overstory and understory layers was positively correlated, while species richness was negatively correlated between the two layers. Diversity in the understory was mainly correlated with soil conditions. Understory LAI was positively correlated with overstory LAl in xeric and mesic plots, while no correlations were found in the moist plot. Overall, our results suggest that site conditions (soil conditions and water availability) are the major drivers of understory and overstory dynamics in the study forest. Hence, local site conditions and the understory should be carefully considered in the management of mixed floodplain forests.
\end{abstract}

Keywords: Deciduous Forests, Functional Diversity, Diversity Measure, Hemispherical Photography, Leaf Area Index

2003, Balvanera et al. 2006, Burrascano et al. 2008, Gamfeldt et al. 2013). New silvicultural systems have emerged during recent decades, based on the assumption that diversity patterns and ecological processes are more likely to persist when disturbances due to management mimic the patterns and processes of natural distur-
(1) Consiglio per la ricerca in agricoltura e l'analisi dell'economia agraria, Forestry Research Center (CREA-SEL), Arezzo (Italy); (2) National Forest Service, National Center for the Study and Conservation of Forest Biodiversity "Bosco Fontana" (CNBFVR), str. Mantova 29, I-46045 Marmirolo, MN (Italy); (3) National Forest Service, National Center for Study and Conservation of Forest Biodiversity "Bosco Fontana", National Taxonomic Laboratory for Invertebrates (CNBFVR-LANABIT), v. Tomaso Da Vico 1, I-37123 Verona (Italy)

@ Francesco Chianucci (fchianucci@gmail.com)

Received: Aug 03, 2015 - Accepted: May 06, 2016

Citation: Chianucci F, Minari E, Fardusi MJ, Merlini P, Cutini A, Corona P, Mason F (2016). Relationships between overstory and understory structure and diversity in semi-natural mixed floodplain forests at Bosco Fontana (Italy). iForest 9: 919-926. - doi: 10.3832/ifor1789009 [online 2016-08-21]

Communicated by: Gianluca Piovesan bances (Decocq et al. 2004, Vandekerkhove et al. 2009). Management regimes mimicking natural disturbances can contribute to diversify stand structure, and this may increase biodiversity through time (Falinski 1989, Frelich \& Reich 2003, Campetella et al. 2004) whilst aiming at economic targets and minimizing modifications of the forests (Emborg et al. 2000).

Close-to-nature forest management requires a comprehensive knowledge of the stand structure, diversity and species interactions naturally occurring in forest ecosystems (Butler-Manning 2008). In the last decades, the number of studies conducted in natural forests sharply increased (Falinski 1989, Scheller \& Mladenoff 2002, Campetella et al. 2004, Petritan et al. 2012, Sabatini et al. 2013). Forest stand structure is an important factor in determining species diversity (Larsson 2001, Marchetti 2004, Corona \& Marchetti 2007) which is a combination of species richness and their relative abundance (Newton 2007). Functional diversity is another component of species diversity which has received much less attention in the scientific literature, though recent studies highlighted its crucial impor- 
tance in shaping the ecosystem processes (Díaz \& Cabido 2001).

The composition of overstory species in the forest may influence understory vegetation diversity and composition (Palik \& Engstrom 1999). Forest overstory-understory relationships are complex and mutual, but are dominated by the overstory canopy structure which affects the availability of different resources on the forest floor (Scheller \& Mladenoff 2002, Burrascano et al. 2011, Burton et al. 2011, Cutini et al. 2015). Leaf Area Index (LAl) is a canopy attribute often used to analyze forest overstory-understory relationships (Macfarlane et al. 2010) and to understand the structure and functions of forest ecosystems at various scales (Bond-Lamberty et al. 2002). $\mathrm{LAl}$ is strongly influenced by species, climate, soil fertility and tree density (Gholz 1982, Angelini et al. 2015). Overstory LAl has strong influence on understory light availability, regeneration and successional dynamics (Lambers et al. 1998). Several studies investigated both overstory and understory LAI in boreal forests (Constabel \& Lieffers 1996, Aubin et al. 2000) and in temperate mountain forests (Augusto et al. 2003, Chianucci et al. 2014), but these measurements had rarely been taken in temperate floodplain forest.

Floodplain forests (one of the 14 categories under the European Forest Types classification framework - Barbati et al. 2014) are highly-dynamic and communityrich natural ecosystems among the most threatened in Europe. Indeed, about 90\% of the original floodplain forests disappeared in the last century (Ward et al. 1999), mainly due to anthropogenic impacts (Capon et al. 2013, Mosner et al. 2015). These ecosystems are generally described as "azonal" (Klimo \& Hager 2001), meaning that local vegetation community is more affected by local environmental conditions (e.g., flooding) than by overall climatic constraits. Hydrologic conditions are the most prominent features driving the ecological processes in floodplains (Gosselink et al. 1990, Lugo et al. 1990, Carter 1996), and affecting the composition and structure of floodplain forest communities (Light et al. 2002).

The semi-natural reserve of "Bosco Fontana" is one of the last remaining floodplain forests in northern Italy (Zapponi et al. 2014), and one of the most endangered ecosystems in Europe (Schlaghamersky 2000). The forest has been managed as coppice with standards until the 1980s, when the reserve was created. Since then, the lack of human disturbances has led to an increasing incidence of the natural processes on forest structure and patterns. Most of the forested area consists of hornbeam (Carpinus betulus), pedunculate oak (Quercus robur), northern red oak (Q. rubra) and Turkey oak (Q. cerris) that prevails in the overstory (Dalponte et al. 2007). The high level of diversity and naturalness of the stands makes this forest an ideal site for studying structure and dynamics in mixed floodplain forests.

The aim of the study was to investigate the structure, diversity, composition, and LAl of forest overstory and understory at Bosco Fontana from 1995 to 2005, as well as to assess the influence of the environmental factors on the main structural and diversity parameters. We analyzed how overstory and understory structure did vary according to soil and environmental conditions. Our specific goals are summarized by the following questions: (i) how do overstory and understory layers vary in taxonomic, structural and functional diversity among xeric, mesic and moist sites? (ii) what are the relationships between overstory and understory layers among xeric, mesic and moist sites? (iii) what is the relationship between understory structure and diversity related to environmental conditions?

\section{Material and methods}

\section{Study site}

Bosco Fontana is a State Natural Reserve in northern Italy $\left(45^{\circ} 12^{\prime} \mathrm{N}, 10^{\circ} 44^{\prime} \mathrm{E}\right)$. The climate is continental, with long, cold winters and hot, humid summers. The average annual temperature is $13.2^{\circ} \mathrm{C}$ and the average annual rainfall was $658 \mathrm{~mm}$ (Campanaro et al. 2007). Eighty-five percent of the Reserve is covered by an ancient floodplain forest and a semi-natural woodland (Mason 2002, 2004) belonging to the Sub-Atlantic and medio-European oak or oakhornbeam forests of the Carpinion betuli (code 9160, Habitats Directive - 1992/43/ CEE). Six permanent monitoring plots were sampled in 1995 and 2005 based on the "SILVI-STAR" system (Koop 1989). These plots were managed as coppice with stan- dards until the '80s and then left to the natural evolution (Mason 2003). The only exception was plot ID5, where the alien species red oak (Quercus rubra) was established after the second World War, which is currently under progressive removal through interventions aimed at increasing the dead wood (Cavalli \& Mason 2003, Zapponi et al. 2014).

A survey was conducted in three out of the six permanent plots, which were chosen as representative of the overstory and understory composition of the Natural Reserve. In particular, plots ID1, ID2 and ID3 reflect the xeric, mesic and moist regime variant of the oak-hornbeam forest, respectively.

The forest overstory survey was conducted in core areas $(70 \times 140 \mathrm{~m})$ established within each of the three aforementioned plots, while understory was surveyed in a central area $(2 \times 100 \mathrm{~m})$ nested within each core area (see below). Three additional $10 \times 100 \mathrm{~m}$ plots (ID4, ID5, ID6) were established for the analysis of the overstory, each with a nested area of $2 \times 100 \mathrm{~m}$ for the understory survey. The plots were categorized into three moisture regime variants (xeric, mesic, moist conditions) based on soil moisture measurements (Mason 2004). The main stand attributes of the study plots in the two inventory years (1995, 2005) are listed in Tab. 1.

\section{Stand structure and composition}

All vascular plants with height above 1.30 $\mathrm{m}$ and diameter above $5 \mathrm{~cm}$ were classified as overstory in both surveys (1995 and 2005). Each plant was identified at the species level and its diameter at breast height $(1.30 \mathrm{~m})$ and height measured. Stand structure, diameter distribution and species basal area contribution was compared between the two inventories to assess change in overstory structure and composition.

Within each monitoring plot, fifty $2 \times 2 \mathrm{~m}$ permanent understory sub-plots were established along a linear transect at the center of each monitoring plot. The understory survey was conducted during periods of peak vegetation cover (July-August) in both 1995 and 2005. Each vascular plant was identified at the species level and its cover-abundance estimated using the Braun-Blanquet scale, which was converted to percentage cover values.

\section{Diversity indices}

Taxonomic diversity at both overstory and understory level was measured as species richness $(S R)$ and Shannon's index $(H)$. Functional diversity at both levels was measured as functional dispersion (FD) as proposed by Laliberté \& Legendre (2010). First, the mean distance of each species to the centroid $c_{\mathrm{i}}$ of the $x_{\mathrm{j}}$ species-by-trait matrix is calculated (eqn. 1 ):

$$
c_{i}=\frac{\sum a_{j} x_{i j}}{\sum a_{j}}
$$


where $a_{\mathrm{j}}$ is the abundance of the species $j$ and $x_{\mathrm{ij}}$ is the attribute of the species $j$ for the trait $i$. The index $F D$ is then computed as the weighted mean distance $z$ to the weighted centroid (eqn. 2):

$$
F D=\frac{\sum a_{j} z_{j}}{j}
$$

where $a_{\mathrm{i}}$ is the abundance of the species $j$ and $z_{\mathrm{j}}$ is the Euclidean distance of the species $j$ to the centroid of the species-bytrait matrix. This index is strongly correlated with Rao's quadratic entropy $Q$ (Rao 1982) as both indices estimate the dispersion of species in the traits space, weighted by their relative abundances.

Shade tolerance and drought tolerance were the functional traits considered in this analysis. Both these traits are relevant in terms of ecosystem dynamics and management (Roberts \& Gilliam 1995, Bartha et al. 1998). Species' values for both traits were obtained from Niinemets \& Valladares (2006), or from additional literature sources when not available therein (e.g., Mondoni et al. 2009, Sobolewska et al. 2013, Pivovaroff et al. 2014). The full list of species' values for shade and drought tolerance is reported in Tab. S1 (Supplementary material). The $F D$ index was computed separately for each trait and combining both traits using the "FD" package (Laliberté \& Legendre 2010) and the R software ( $\mathrm{R}$ Core Development Team, Vienna).

For the overstory layer, species basal area was used as surrogate of abundance in the computation of both the overstory functional dispersion $\left(F D_{\circ}\right)$ and the Shannon's Index $\left(H_{\circ}\right)$. The species' cover was used as a surrogate of species abundance to compute understory functional dispersion $\left(F D_{\cup}\right)$ and the Shannon's index $\left(H_{\cup}\right)$. Moreover, understory diversity indices were calculated for each sub-plot quintuplet (i.e., every $10 \mathrm{~m}$ along the transect) to obtain a reasonable minimum number of samples in the analyses.

\section{Leaf area index survey}

Leaf area index of both overstory and understory layers was estimated in a subset of three plots (one xeric, one mesic and one moist plot) according to Chianucci \& Cutini (2013) and Chianucci et al. (2014). Downward-facing images of the understory layer and upward-facing images of the overstory layer were collected in 2005 using a Nikon Coolpix 4500 equipped with a FC-E8 fisheye lens converter set to F1, minimum aperture ( $F$ 5.3) and one-stopunderxposure. For each monitoring plot, 120 understory images and 120 overstory images were collected along a grid, with sampling points spaced $10 \mathrm{~m}$ each other. Images were collected close to sunrise at a height of $1.5 \mathrm{~m}$. Overstory images were first corrected to a gamma function of 1.0 and then classified using a single binary threshold in Winscanopy ${ }^{\circledast}$ (Regent Instruments, S.te-Foy, Quebec, Canada). Understory images were classified using the
$L A B 2$ classification method of Macfarlane \& Ogden (2012) in MATLAB ${ }^{\oplus}$. Overstory and understory classified images were then analyzed in Winscanopy for estimation of the leaf area index. The hemisphere of each image was divided into 7 zenith rings with a zenith angle range of $0-70^{\circ}$ and 8 azimuth segments. Leaf area index corrected for clumping was finally estimated by averaging the generalized LAl-2000 method and the ellipsoidal LAI method, for transformed gap fraction data (log method - Lang \& Xiang 1986).

\section{Comparisons between overstory and understory layers}

To evaluate the change in the overstory composition among sites, we compared the composition and the structure of the stands between the two inventory years (1995, 2005). Further, leaf area indices and the selected functional and taxonomic indices were compared among sites and dates. The significance of the relationships between overstory and understory attributes was tested using the Pearson's $r$ cor- relation test.

To explore the relationship between the understory and environmental conditions, we used Ellenberg's indicators for light $(L)$, temperature $(T)$, soil nutrient $(N)$ and soil reaction $(R)$, and a combination of these traits, which were assessed for the Italian flora by Pignatti et al. (2005) and are currently available from the "TR8" package (Bocci 2015) for the R software. The understory cover-abundance values were used as weighted averages for computing Ellenberg's indicators. This approach is an alternative to direct field measurements of site characteristics (Ter Braak \& Wiertz 1994, Decocq et al. 2004). Environmental effects on understory attributes were investigated by the Pearson's $r$ correlation test.

\section{Results}

\section{Stand structure and composition}

The studied plots generally showed a reverse-J diameter distribution (Fig. 1), which was more pronounced in the second inventory in 2005. Stand basal area in-
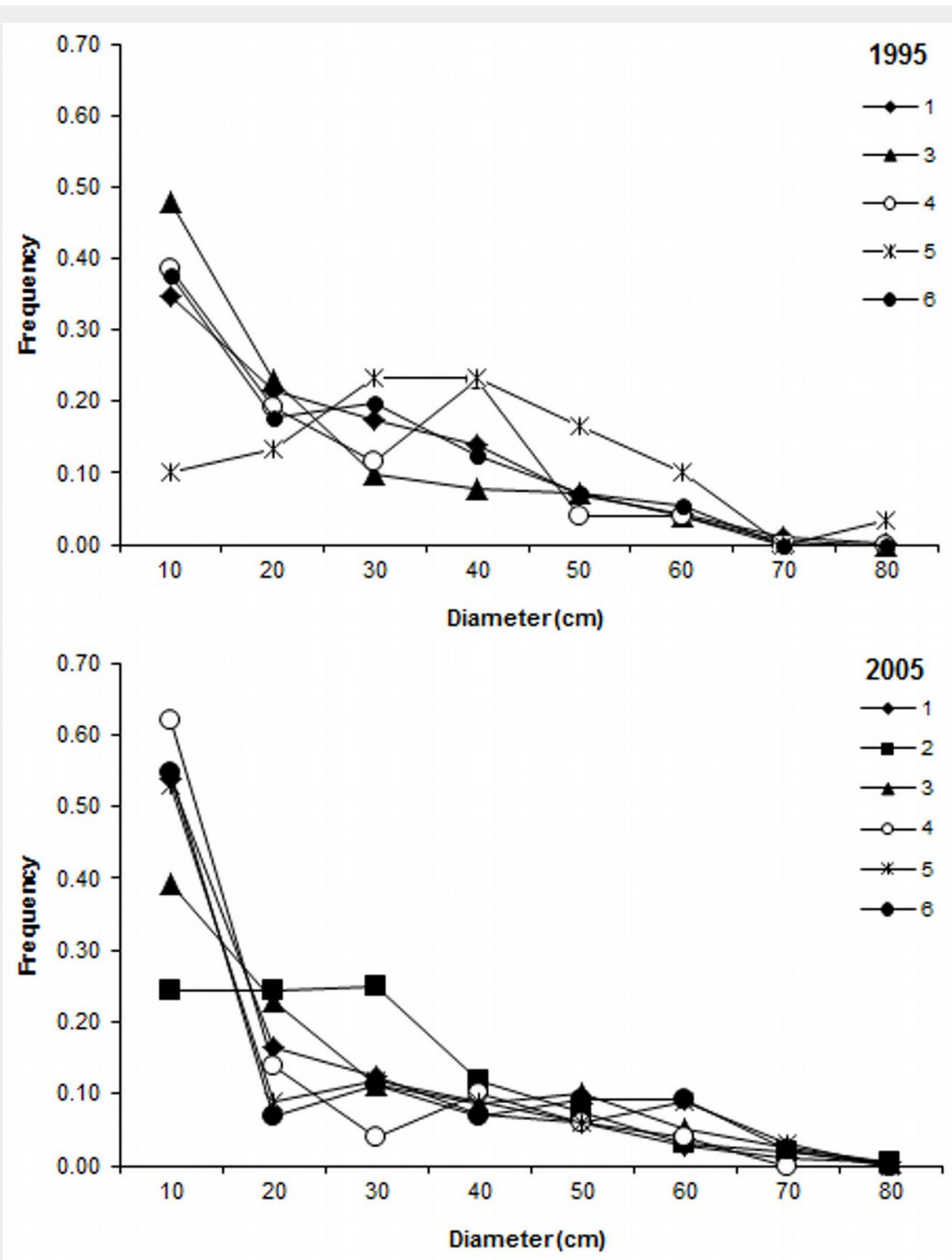

Fig. 1 - Distribution of tree stem diameters at breast height in the studied plots in 1995 (top) and 2005 (bottom). 
Tab. 2 - Basal area contribution $\left(\mathrm{m}^{2} \mathrm{ha} \mathrm{a}^{-1}\right)$ by each species surveyed in the overstory plots at the two inventory years (1995, 2005).

\begin{tabular}{|c|c|c|c|c|c|c|c|c|c|c|c|c|}
\hline \multirow{2}{*}{ Species } & \multicolumn{6}{|l|}{1995} & \multicolumn{6}{|l|}{2005} \\
\hline & ID1 & ID2 & ID3 & ID4 & ID5 & ID6 & ID1 & ID2 & ID3 & ID4 & ID5 & ID6 \\
\hline Acer campestre & 0.04 & 0.82 & 0.19 & 0.15 & - & - & 0.20 & 0.51 & 0.25 & 0.32 & - & - \\
\hline Alnus glutinosa & - & - & 3.00 & - & 2.23 & - & - & - & 2.72 & - & 2.12 & - \\
\hline Corylus avellana & 0.05 & 0.04 & 0.65 & 0.02 & - & 0.21 & 0.57 & 0.17 & 0.96 & 0.77 & 0.42 & 0.43 \\
\hline Carpinus betulus & 9.76 & 11.00 & 6.46 & 8.61 & 8.44 & 7.60 & 12.04 & 11.60 & 7.04 & 8.93 & 7.97 & 7.58 \\
\hline Cornus mas & - & 0.00 & - & - & - & - & 0.01 & 0.01 & 0.00 & - & 0.08 & 0.05 \\
\hline $\begin{array}{l}\text { Crataegus } \\
\text { oxyacantha }\end{array}$ & 0.01 & 0.00 & 0.04 & 0.02 & 0.05 & - & 0.01 & 0.00 & 0.00 & - & - & - \\
\hline Cornus sanguinea & 0.00 & - & 0.01 & - & - & - & - & - & - & - & - & - \\
\hline Clematis vitalba & - & 0.01 & 0.00 & - & - & 0.14 & - & - & - & - & - & - \\
\hline Fraxinus oxycarpa & - & - & 7.28 & - & - & - & - & - & 12.17 & - & - & - \\
\hline Fraxinus ornus & 0.02 & 3.16 & 0.01 & 0.75 & - & 1.29 & 0.10 & 7.85 & 0.00 & 1.37 & - & 0.57 \\
\hline Hedera helix & - & 0.01 & - & - & - & - & 0.07 & - & 0.01 & - & - & 0.00 \\
\hline Juglans regia & - & - & - & - & - & 1.32 & - & - & - & - & - & 2.46 \\
\hline Malus sylvatica & 0.05 & - & 0.03 & - & - & 0.05 & 0.02 & - & - & - & - & - \\
\hline Prunus avium & 0.49 & 0.50 & 0.76 & 0.32 & 0.57 & - & 1.07 & 0.58 & 0.84 & 0.37 & 0.71 & - \\
\hline Platanus $x$ acerifolia & - & - & 0.03 & - & - & 1.45 & - & - & 0.04 & - & - & 2.51 \\
\hline Quercus rubra & - & - & - & - & 18.93 & 12.91 & - & - & - & - & 8.86 & 12.26 \\
\hline Quercus cerris & 0.85 & 0.56 & - & 1.04 & - & - & 1.04 & 1.13 & 0.59 & 2.49 & - & - \\
\hline Quercus robur & 8.22 & 7.35 & 5.89 & 2.29 & 0.44 & 1.31 & 7.86 & 8.57 & 6.37 & 3.61 & 0.64 & 0.79 \\
\hline $\begin{array}{l}\text { Robinia } \\
\text { pseudoacacia }\end{array}$ & - & - & 0.07 & - & - & - & 0.02 & - & 0.16 & - & - & - \\
\hline Sambucus nigra & 0.03 & 0.00 & 0.03 & - & - & - & 0.05 & - & 0.01 & 0.08 & 0.02 & - \\
\hline Sorbus torminalis & 0.12 & 0.12 & 0.06 & 0.20 & - & 0.94 & 0.09 & 0.03 & - & 0.23 & - & - \\
\hline Ulmus minor & 0.01 & - & 0.42 & - & - & 0.08 & 0.19 & - & 0.77 & - & 0.03 & 0.07 \\
\hline
\end{tabular}

creased in four out of six plots by values ranging from 15 to $25 \%$ (Tab. 1), likely due to an increase by horn beam, Turkey oak and ash species (Fraxinus ornus, F. oxycarpa) in these plots (Tab. 2). A reduction in basal area of $46 \%$ was observed in one plot (ID5)

due to thinning of red oak (Tab. 2). Basal area was almost unchanged between the two inventories in the remaining plots (Tab. 1).

Horn beam and oaks were the most dominant species, but their relative contribu-
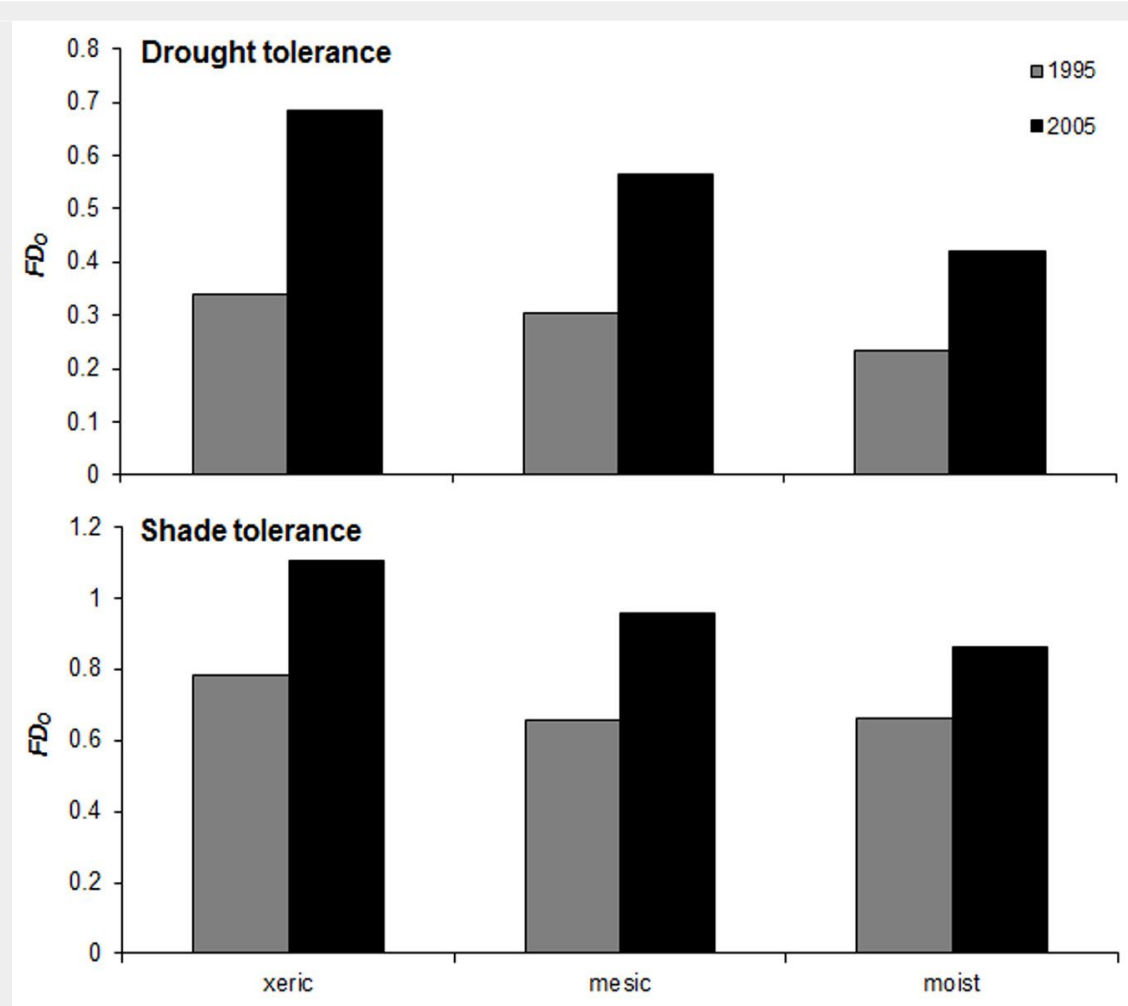

Fig. 2 - Mean values of functional dispersion $\left(F D_{\circ}\right)$ for species' drought tolerance (top) and shade tolerance (bottom) in the overstory layer of the studied plots at the two inventory dates $(1995,2005)$. tion varied according to the hydrological site conditions. The largest abundance of horn beam was observed in the xeric plots, where this species contributed to the total stand basal area between 50 to $64 \%$ in 1995 and between 49 to $52 \%$ in 2005; in the same plots the contribution of oak species varied between 25 and $46 \%$ in 1995 and between 34 to $38 \%$ in 2005. In mesic plots horn beam contributed to the total stand basal area between 28 to $47 \%$ in 1995 and between 28 to $38 \%$ in 2005 , while the contribution of oak species varied between 33 to $63 \%$ in 1995 and between 32 to $49 \%$ in 2005. In the moist plot, more water demanding species (Fraxinus oxycarpa, Alnus glutinosa and Corylus avellana) largely contributed (46-50\%) to the total stand basal area.

\section{Diversity indices}

The number of overstory vascular plant species found in the monitored understory plots (quintuplets) ranged from 6 to 17 . Overstory functional dispersion $\left(F D_{\circ}\right)$ in drought and shade tolerance traits ranged from 0.16 to 1.12 (average \pm standard deviation: $0.44 \pm 0.30$ ) and from 0.58 to 1.16 $(0.85 \pm 0.18)$, respectively. The values of $F D_{\circ}$ obtained combining the two traits ranged from 0.62 to $1.63(1.04 \pm 0.30)$. On average, xeric sites showed higher $F D_{0}$ values, while the moist plot showed lower $F D_{\circ}$ values (Fig. 2). Functional diversity increased between the two inventories (Fig. 2). Shannon index $\left(H_{0}\right)$ ranged from 0.99 to $1.68(1.39 \pm 0.22)$; the moist plot showed the highest $H_{0}$ values, while xeric plots showed the lowest.

The number of understory vascular plant species found in the monitored plots 


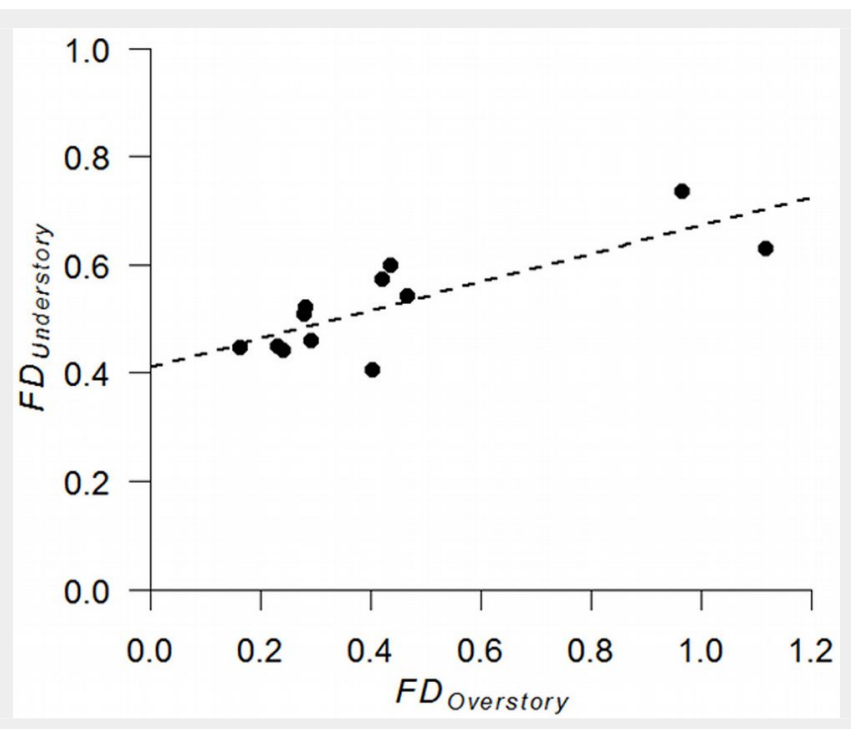

Fig. 3 - Relationship between functional dispersion of drought tolerance $(F D)$ in the overstory and understory layers $(n=12)$.

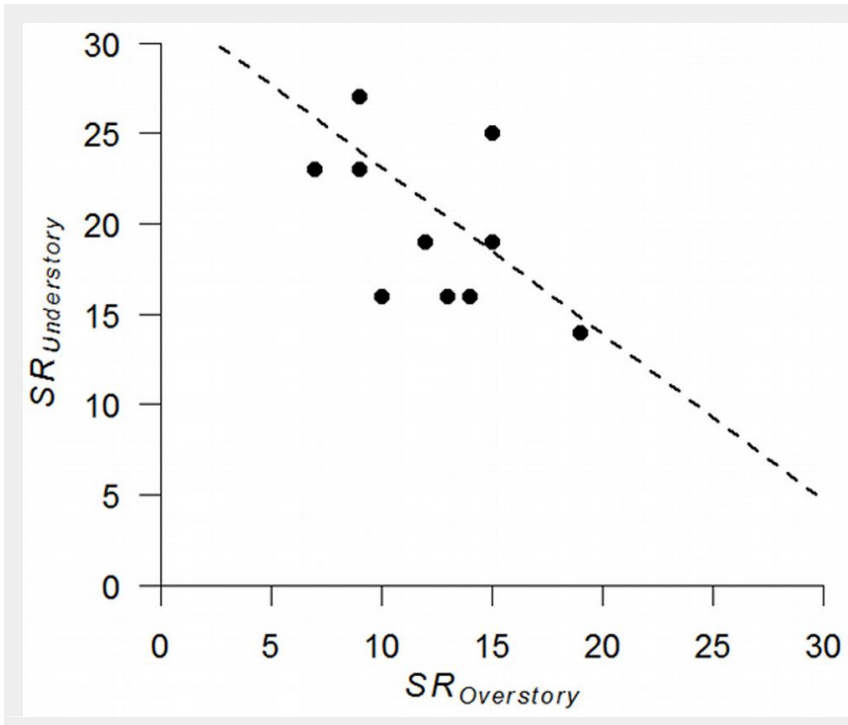

Fig. 4 - Relationship between species richness $(S R)$ of the overstory and understory layers $(n=12)$.

Tab. 3 - Person's $r$ correlation coefficients between understory diversity indices and site environmental characteristics obtained from Ellenberg's indicator values $(n=120)$. $(S R)$ : Species richness; $(F D)$ : functional dispersion; $(H)$ : Shannon's index; $(*)$ : $\mathrm{p}<0.05$; $(* *): p<0.01 ;(* * *): p<0.001$

\begin{tabular}{lccccc}
\hline Attribute & $\begin{array}{c}\text { Light } \\
(\mathbf{L})\end{array}$ & $\begin{array}{c}\text { Temperature } \\
(\mathbf{T})\end{array}$ & $\begin{array}{c}\text { Soil reaction } \\
(\mathbf{R})\end{array}$ & $\begin{array}{c}\text { Soil nutrient } \\
(\mathbf{N})\end{array}$ & $\begin{array}{c}\text { Combined } \\
\text { Ellenberg Index }\end{array}$ \\
\hline$S R \cup$ & 0.14 & 0.01 & 0.07 & $0.23^{*}$ & $0.24^{* *}$ \\
$F D \cup$ dry & $0.40^{* * *}$ & $0.51^{* * *}$ & $0.36^{* * *}$ & $0.30^{* * *}$ & $0.22^{*}$ \\
$F D \cup$ shade & $-0.29^{* * *}$ & -0.17 & 0.13 & 0.10 & 0.01 \\
$F D \cup$ dry shade & $0.22^{* *}$ & $0.33^{* * *}$ & $0.35^{* * *}$ & $0.23^{*}$ & $0.23^{*}$ \\
Understory cover & $0.25^{* *}$ & -0.13 & $-0.23^{*}$ & -0.06 & $0.48^{* * *}$ \\
$H_{\cup}$ & 0.13 & -0.04 & 0.06 & $0.20^{*}$ & $0.53^{* * *}$ \\
\hline
\end{tabular}

ranged from 4 to 20 . Understory functional dispersion $\left(F D_{\cup}\right)$ in drought and shade tolerance traits ranged from 0.12 to $1.14(0.53$ $\pm 0.19)$ and from 0.06 to $0.84(0.42 \pm 0.15)$, respectively; $F D_{\cup}$ obtained combining the two traits ranged from 0.15 to $1.32(0.73 \pm$ 0.20). Similarly to $F D_{\circ}$, xeric sites showed on average higher $F D_{\cup}$ values, while the moist plot showed lower $F D_{\cup}$ values. Shannon's index $H_{\mathrm{u}}$ ranged from 0.51 to 2.78 (1.61 \pm 0.41$)$; unlike $H_{0}$, xeric plots showed on average higher $H_{\cup}$ values, while the moist plot showed lower $H_{\cup}$ values.

Understory diversity indices showed significant correlations with site environmental characteristics obtained from Ellenberg's indicator values (Tab. 3). The dispersion in shade tolerance was negatively correlated with light value (L). Conversely, the dispersion in drought tolerance was positively correlated with all the environmental factors. Species richness and the Shannon's index were positively correlated with soil nutrient $(\mathrm{N})$ and the combined environmental index. Understory cover was positively correlated with light value (L) and negatively correlated with soil reaction $(R)$. Analysis of overstory and understory relationship revealed a significant positive correlation in drought tolerance between the two layers $(r=0.82, n=12, p=0.01$ - Fig. 3$)$.
In addition, understory species richness was slightly negatively correlated with overstory species richness $(r=-0.57, n=12$, $p=0.055$ - Fig. 4).

\section{Leaf area index survey}

Overstory LAl averaged ( \pm SE) $4.1 \pm 0.1$, $4.4 \pm 0.1$ and $3.7 \pm 0.1$ in the xeric, mesic and moist plots, respectively. Understory leaf area index averaged $1.4 \pm 0.1,1.5 \pm 0.1$ and 1.1 in the xeric, mesic and moist plots, respectively. Understory $\mathrm{LAI}\left(L_{U}\right)$ was positively correlated with overstory leaf area index $\left(L_{0}\right)$ in both the xeric $\left(L_{U}=0.44 \cdot L_{O}\right.$ $0.38, \mathrm{n}=120, \mathrm{r}=0.75)$ and mesic $\left(L_{\mathrm{U}}=0.36\right.$. $L_{0}-0.09, n=120, r=0.71$ ) plots, while was uncorrelated in the moist plot $\left(L_{U}=0.08\right.$. $\left.L_{0}+0.79, n=120, r=0.01\right)$.

\section{Discussion}

The studied stands were characterized by a complex and highly diverse structure, which is typical of floodplain forests, as indicated by the structural and diversity indices tested. However, our results revealed that site conditions are an important aspect in explaining species distribution patterns and their interaction. Species composition in the overstory layer appeared to vary according to soil water availability, being more similar in xeric and mesic plots, in which hornbeam and oaks are the dominant species, and favoring more hygrophilus species in the moist site. Such different overstory composition is reflected by the functional dispersion indices, which increased from moist to xeric conditions. A decreasing correlation between understory and overstory LAls was also observed with respect to increasing soil water availability.

The significant and positive correlation observed in drought tolerance and leaf area indices between understory and overstory layers suggest a mutual influence on the structure and dynamics of the two layers in temperate broadleaf forests. Further, the positive correlation between the leaf area indices of the two layers in xeric and mesic plots is contrasting with previous studies conducted in managed forests, which reported an inverse relationship between overstory and understory LAI (Macfarlane et al. 2010, Kodar et al. 2011, Chianucci et al. 2014). The understory of mesic and xeric plots analyzed in this study was dominated by Butcher's broom (Ruscus aculeatus, average cover 53\%), followed by the shade-tolerant species Anemone nemorosa (16\%) and the drought-tolerant Vinca minor (12\%). Therefore, we attributed the positive correlation between overstory and 
understory LAl observed in these plots to the large abundance of Ruscus aculeatus, which combines drought and shade tolerance in limiting site conditions (Pivovaroff et al. 2014).

The high functional dispersion observed in the plots characterized by relatively drier conditions suggests that these stands are undergoing an early successional stage, in which ruderal species with wide ecological amplitude are exhibiting large competition for limited resources. In this context, the large dominance of Ruscus aculeatus, combined with its high tolerance, may further displace other species in the understory by strong competition, thus limiting their presence in this successional stage (Campetella et al. 2004). In the moist plot, Butcher's broom showed a lower occurrence (29\%) in the understory, while species associated with fertile and water-rich soils like Euonymous europaeus (average cover 17\%), Allium ursinum (27\%), Anemone ranunculoides (14\%) and Corylus avellana (14\%) had fairly high frequency. In the moist plot, LAI proved to be uncorrelated between the two layers, thus it could be hypothesized that this stand reflects a more mature successional stage, in which the higher resource availability have promoted niche differentiation and favored late-successional (habitat-specialist) species (Campetella et al. 2004), and where the overstoryunderstory dynamics are close to the equilibrium (Aubert et al. 2003). Taken together, the above results agree with previous reports indicating that different overstory structures can determine different environmental conditions, which drive different plants strategies aimed at tolerating stressful vs. competitive, resource-rich environments (Wright 2002, 2004, Sabatini et al. 2013). In general, our results emphasize the importance of the understory layer (often neglected in forest management decision) because of its crucial role in driving the future dynamics of the forests (Gilliam 2007).

Based on our results, we conclude that local site conditions should be carefully considered in the management of mixed temperate floodplain forests. In the more resource-limited stands, a strong interplay between the overstory and understory layers may facilitate a fast recharge of nutrient pools (Swanson et al. 2010) and provide a greater resilience to environmental stresses (Ares et al. 2010). Silvicultural practices aimed at the conservation of forest diversity should be targeted at maintaining an active dynamics in the stand by reaching a compromise between overstory canopy removal and environmental resources availability after the intervention. Finally, an effective assessment of the interplay between overstory and understory layers should be included in forest monitoring systems (Corona 2016), in order to support forest planning and management decisions.

\section{Acknowledgements}

FM designed the experiment and coordinated the work. FC, EM and MJF conducted the experiment, analyzed the data and wrote the paper. PM and AC collected the data. PC provided the conceptual support. FC was supported by the Project "ALForLab" (PON03PE_00024_1) co-funded by the Italian Operational Programme for Research and Competitiveness (PON $R \& C)$ 2007-2013, through the European Regional Development Fund (ERDF) and national resource (Revolving Fund - Cohesion Action Plan (CAP) MIUR). We are grateful to the anonymous reviewers for the useful suggestions that improved an early version of the manuscript.

\section{References}

Angelini A, Corona P, Chianucci F, Portoghesi L (2015). Structural attributes of stand overstory and light under the canopy. Annals of Silvicultural Research 39: 23-31. [online] URL: http:// dspace.unitus.it/bitstream/2067/2667/1/ASR_Str ucturalattributesofstandoverstory.pdf

Ares A, Neill AR, Puettmann KJ (2010). Understory abundance, species diversity and functional attribute response to thinning in coniferous stands. Forest Ecology and Management 260: 1104-1113. - doi: 10.1016/j.foreco.2010.06. 023

Aubert M, Alard D, Bureau F (2003). Diversity of plant assemblages in managed temperate forests: a case study in Normandy (France). Forest Ecology and Management 175: 321-337. - doi: 10.1016/S0378-1127(02)00215-3

Aubin I, Beaudet M, Messier C (2000). Light extinction coefficients specific to the understory vegetation of the southern boreal forest, Quebec. Canadian Journal of Forest Research 30 (1): 168-177. - doi: 10.1139/x99-185

Augusto L, Dupouey J, Ranger J (2003). Effects of tree species on understory vegetation and environmental conditions in temperate forests. Annals of Forest Science 60 (8): 823-831. - doi: 10.1051/forest:2003077

Balvanera P, Pfisterer AB, Buchmann N, He JS, Nakashizuka T, Raffaelli D, Schmid B (2006). Quantifying the evidence for biodiversity effects on ecosystem functioning and services. Ecology letters 9: 1146-1156. - doi: 10.1111/j.14610248.2006.00963.x

Barbati A, Marchetti M, Chirici G, Corona P (2014). European forest types and forest Europe SFM indicators: tools for monitoring progress on forest biodiversity conservation. Forest Ecology and Management 321: 145-157. doi: 10.1016/j.foreco.2013.07.004

Bartha S, Czárán T, Podani J (1998). Exploring plant community dynamics in abstract coenostate spaces. Abstracta Botanica 22: 49-66. [online] URL: http://www.jstor.org/stable/4351 8937

Bocci G (2015). TR8: an R package for easily retrieving plant species traits. Methods in Ecology and Evolution 6: 347-350. - doi: 10.1111/2041210X.12327

Bond-Lamberty B, Wang C, Gower ST, Norman J (2002). Leaf area dynamics of a boreal black spruce fire chronosequence. Tree Physiology 22: 993-1001. - doi: 10.1093/treephys/22.14.993
Burrascano S, Lombardi F, Marchetti M (2008). Old-growth forest structure and deadwood: are they indicators of plant species composition? A case study from central Italy. Plant Biosystems 142 (2): 313-323. - doi: 10.1080/112635 00802150613

Burrascano S, Sabatini FM, Blasi C (2011). Testing indicators of sustainable forest management on understorey composition and diversity in southern Italy through variation partitioning. Plant Ecology 212: 829-841. - doi: 10.1007/s11258010-9866-y

Burton JI, Mladenoff DJ, Clayton MK, Forrester JA (2011). The roles of environmental filtering and colonization in the fine-scale spatial patterning of ground-layer plant communities in north temperate deciduous forests. Journal of Ecology 99: 764-776. - doi: 10.1111/j.1365-2745.20 11.01807.x

Butler-Manning D (2008). Stand structure, gap dynamics and regeneration of a semi-natural mixed beech forest on limestones in central Europe - a case study. Universität Freiburg, Freiburger Forstliche, Forschung, Germany, pp. 38. Campanaro A, Hardersen S, Mason F (2007). Piano di gestione della Riserva Naturale Statale e Sito Natura 2000 "Bosco Fontana" [Management Plan of the State Natural Reserve and Nature 2000 site "Bosco Fontana"]. Quaderni Conservazione Habitat 4, Cierre edizioni, Verona, Italy, pp. 220. [in Italian]

Campetella G, Canullo R, Bartha S (2004). Coenostate descriptors and spatial dependence in vegetation-derived variables in monitoring forest dynamics and assembly rules. Community Ecology 5 (1): 105-114. - doi: 10.1556/ComEc.5.20 04.1.10

Capon J, Chambers LE, Mac Nally R, Naiman RJ, Davies P, Marshall N, Pittock J, Reid M, Capon T, Douglas M, Catford J, Baldwin DS, Stewardson M, Roberts J, Parsons M, Williams SE (2013). Riparian ecosystems in the $21^{\text {st }}$ century: hotspots for climate change adaptation. Ecosystems 16: 359-381. - doi: 10.1007/s10021-0139656-1

Carter V (1996). Wetland hydrology, water quality, and associated functions. In: "National water summary on wetland resources" (Fretwell JD, Williams JS, Redman PJ eds). Water-Supply Paper no. 2425, US Geological Survey, Washington, DC, USA, pp. 35-48. [online] URL: http:// books.google.com/books?id=UDU411JLwl8C

Cavalli R, Mason F (2003). Techniques for reestablishment of dead wood for saproxylic fauna conservation. LIFE Nature project NAT/IT/ 99/6245 "Bosco della Fontana" (Mantova, Italy). Scientific Reports 2, Centro Nazionale per lo Studio e la Conservazione della Biodiversità Forestale di Verona - Bosco della Fontana, Gianluigi Arcari Editore, Mantova, Italy, pp. 112. Chianucci F, Cutini A (2013). Estimation of canopy properties in deciduous forests with digital hemispherical and cover photography. Agricultural and Forest Meteorology 168: 130-139. doi: 10.1016/j.agrformet.2012.09.002

Chianucci F, Puletti N, Venturi E, Cutini A, Chiavetta U (2014). Photographic assessment of overstory and understory leaf area index in beech forests under different management regimes in Central Italy. Forestry Studies 61: 2734. - doi: 10.2478/fsmu-2014-0008 
Constabel AJ, Lieffers VJ (1996). Seasonal patterns of light transmission through boreal mixedwood canopies. Canadian Journal of Forest Research 26 (6): 1008-1014. - doi: 10.1139/×26-111 Corona P, Marchetti M (2007). Outlining multipurpose forest inventories to assess the ecosystem approach in forestry. Plant Biosystems 2: 243-251. - doi: 10.1080/11263500701401836 Corona P (2016). Consolidating new paradigms in large-scale monitoring and assessment of forest ecosystems. Environmental Research 144: 8-14. - doi: 10.1016/j.envres.2015.10.017

Cutini A, Chianucci F, Giannini T, Manetti MC, Salvati $L$ (2015). Is anticipated seed cutting an effective option to accelerate transition to high forest in European beech (Fagus sylvatica L.) coppice stands? Annals of Forest Sciences 72: 631-640. - doi: 10.1007/s13595-015-0476-7

Dalponte M, Gianelle D, Bruzzone L (2007). Use of hyperspectral and LiDAR data for classification of complex forest areas. In: "Canopy analysis and dynamics of a floodplain forest". Rapporti scientifici 3: 25-37.

Decocq G, Aubert M, Dupont F, Alard D, Saguez $R$, Wattez-Franger A, De Foucault $B$, DelelisDusollier A, Bardat J (2004). Plant diversity in a managed temperate deciduous forest: understorey response to two silvicultural systems. Journal of Applied Ecology 41: 1065-1079. - doi: 10.1111/j.0021-8901.2004.00960.x

Díaz S, Cabido M (2001). Vive la différence: plant functional diversity matters to ecosystem processes. Trends in Ecology and Evolution 16 (11): 646-655. - doi: 10.1016/S0169-5347(01)02283-2

Emborg J, Christensenb M, Heilmann-Clausen J (2000). The structural dynamics of Suserup Skov, a near-natural temperate deciduous forest in Denmark. Forest Ecology and Management 126: 173-189. - doi: 10.1016/S0378-1127(99) 00094-8

Falinski JB (1989). Succession, regeneration and fluctuation in the Bialowieza Forest (NE POland). In: "Temporal and Spatial Patterns of Vegetation Dynamics". Springer, Netherlands, pp. 115-128.

Frelich LE, Reich PB (2003). Perspectives on development of definitions and values related to old-growth forests. Environmental Review 11: 9-22. - doi: 10.1139/a03-011

Gamfeldt L, Snäll T, Bagchi R, Jonsson M, Gustafsson L, Kjellander P, Ruiz-Jaen MC, Fröberg $M$, Stendahl J, Philipson CD, Mikusinski G, Andersson $\mathrm{E}$, Westerlund $\mathrm{B}$, Andrén $\mathrm{H}$, Moberg F, Moen J, Bengtsson J (2013). Higher levels of multiple ecosystem services are found in forests with more tree species. Nature Communications 4: 1340. - doi: $10.1038 /$ ncomms 2328 Gholz HL (1982). Environmental limits on aboveground net primary production, leaf area, and biomass in vegetation zones of the Pacific northwest. Ecology 63: 469-481. - doi: 10.2307/ 1938964

Gilliam FS (2007). The ecological significance of the herbaceous layer in temperate forest ecosystems. BioScience 57: 845-858. - doi: 10.1641/ B571007

Gosselink JG, Lee LC, Muir TA (1990). Ecological processes and cumulative impacts. Mich. Lewis Publishers, Chelsea, UK, pp. 708.

Klimo E, Hager $H$ (2001). The floodplain forest in Europe: current and perspectives. European
Forest Institute Research Report 10, Koninklijke Brill NV, Leiden, Netherlands, pp. 268.

Kodar A, Lang M, Arumäe T, Eenmäe A, Nilson T (2011). Leaf area index mapping with airborne lidar, satellite images and ground measurements in Järvselja Valeri test site. Forestry Studies 55: 11-32. - doi: 10.2478/v10132-011-0099-1

Koop H (1989). Forest dynamics: SILVI-STAR, a comprehensive monitoring system. SpringerVerlag, Wageningen, Netherlands, pp. 229.

Laliberté E, Legendre P (2010). A distance-based framework for measuring functional diversity from multiple traits. Ecology 91: 299-305. - doi: 10.1890/08-2244.1

Lambers H, Chapin FS, Pons TL (1998). Plant physiological ecology. Springer-Verlag, New York, USA, pp. 540.

Lang ARG, Xiang Y (1986). Estimation of leaf area index from transmission of direct sunlight in discontinuous canopies. Agricultural and Forest Meteorology 37: 229-243. - doi: 10.1016/01 68-1923(86)90033-X

Larsson TB (2001). Biodiversity evaluation tools for European forests. EFI Proceedings no. 38, EFI, Joensuu, Finland, pp. 75-81. [online] URL: http://www.efi.int/files/attachments/publicatio ns/proc38 net.pdf\#page $=75$

Light HM, Darst MR, Lewis L, Howell DA (2002). Hydrology, vegetation, and soils of riverine and tidal floodplain forests of the lower Suwannee River, Florida, and potential impacts of flow reductions. Professional Paper 1656-A, US Geological Survey, Washington, DC, USA, pp. 124. [online] URL: http://cat.inist.fr/?aModele=affich eN\&cpsidt $=15463984$

Lugo AE, Brinson M, Brown S (1990). Ecosystems of the world. Forested Wetlands. Elsevier, Amsterdam, Netherlands, vol. 15, pp. 527.

Macfarlane C, Ogden GN (2012). Automated estimation of foliage cover in forest understorey from digital nadir images. Methods in Ecology and Evolution 3 (2): 405-415. - doi: 10.1111/j.2041210X.2011.00151.X

Macfarlane C, Lardner T, Patterson K, Grigg AH (2010). A new model for predicting understorey leaf area from biomass in eucalypt forest to test the ecohydrological equilibrium theory. Methods in Ecology and Evolution 1: 371-379. doi: 10.1111/j.2041-210X.2010.00038.x

Marchetti M (2004). Monitoring and indicators of forest biodiversity in Europe - From ideas to operationality. EFI Proceeding no. 51, European Forest Institute, Joensuu, Finland, pp. 526.

Mason F (2002). Problems of conservation and management. In: "Woodlands of the Po Plain" (Ruffo S ed). Friuli Museum of Natural History, Italian Ministry of the Environment and Territory Protection, Rome, Italy, pp. 91-137.

Mason F (2003). Guidelines and aims of the project Life NAT/IT/99/006245 - Bosco della Fontana: urgent actions on relict habitat. In: Proceedings of the International Symposium "Dead wood: a key to biodiversity" (Mason F, Nardi G, Tisato M eds). Mantova (Italy) 29-31 May 2003. Sherwood 95 (2): 41-43.

Mason F (2004). Dinamica di una foresta della Pianura Padana. Bosco della Fontana. Seconda edizione con linee di gestione forestale [Dynamics of a floodplain forest in the Po valley. Bosco Fontana. Second edition, with forest management guidelines]. Ministero per le Po- litiche Agricole e Forestali-Corpo Forestale dello Stato - Centro Nazionale per lo Studio e la Conservazione della Biodiversità Forestale, Arcari Editore, Mantova, Italy, pp. 226. [in Italian] Meyer P, Tabaku V, Lüpke BV (2003). Die Struktur albanischer Rotbuchen Urwälder Ableitungen für eine naturnahe Buchenwirtschaft [Structural characteristics of Albanian beech (Fagus sylvatica L.) virgin forests - deductions for semi-natural forestry]. Forstw. Cbl 122: 4758. [in German] - doi: 10.1046/j.1439-0337.2003. 02041.x

Mondoni A, Probert R, Rossi G, Hay F (2009). Habitat-related germination behaviour and emergence phenology in the woodland geophyte Anemone ranunculoides L. (Ranunculaceae) from northern Italy. Seed Science Research 19 (03): 137-144. - doi: 10.1017/Sog6025 8509990067

Mosner E, Weber A, Carambia M, Nilson E, Schmitz U, Zelle B, Donath T, Horchler P (2015). Climate change and floodplain vegetation future prospects for riparian habitat availability along the Rhine River. Ecological Engineering 82: 493-511. - doi: 10.1016/j.ecoleng.2015.05.013 Newton AC (2007). Forest ecology and conservation. A handbook of techniques. Oxford University Press, Oxford, UK, pp. 454. [online] URL: http://books.google.com/books?id=I4ISDAAAQ BAJ

Niinemets U, Valladares F (2006). Tolerance to shade, drought and waterlogging of temperate Northern Hemisphere trees and shrubs. Ecological monographs 76 (4): 521-547. - doi: 10.1890/ 0012-9615(2006)076[0521:TTSDAW]2.0.CO;2

Palik B, Engstrom RT (1999). Species composition. In: "Maintaining Biodiversity in Forest Ecosystems" (Hunter MJ ed). Cambridge University Press, Cambridge, UK, pp. 65-94.

Petritan AM, Biris IA, Merce O, Turcu DO, Petri$\tan I C$ (2012). Structure and diversity of a natural temperate sessile oak (Quercus petraea L.) European Beech (Fagus sylvatica L.) forest. Forest Ecology and Management 280: 140-149. doi: 10.1016/j.foreco.2012.06.007

Pignatti S, Menegoni P, Pietrosanti S (2005). Bioindicazione attraverso le piante vascolari. Valori di indicazione secondo Ellenberg (Zeigerwerte) per le specie della Flora d'Italia [Using vascular plants as bioindicators. Ellenberg's values for the species of the Italian flora]. Braun-Blanquetia 39: 1-97. [in Italian]

Pivovaroff A, Sharifi R, Scoffoni C, Sack L, Rundel $P(2014)$. Making the best of the worst of times: traits underlying combined shade and drought tolerance of Ruscus aculeatus and Ruscus microglossum (Asparagaceae). Functional Plant Biology 41 (1): 11-24. - doi: 10.1071/FP13047

Rao CR (1982). Diversity and dissimilarity coefficients: a unified approach. Theoretical Population Biology 21 (1): 24-43. - doi: 10.1016/00405809(82)90004-1

Reich PB, Frelich L (2002). Temperate deciduous forests. In: "Encyclopedia of Global Environmental Change (Vol. 2)" (Munn T, Mooney HA, Canedell JG). John Wiley and Sons, Chichester, USA, pp. 565-569. [online] URL: http://citese erx.ist.psu.edu/viewdoc/download?doi=10.1.1.6 57.2202

Roberts MR, Gilliam FS (1995). Patterns and mechanisms of plant diversity in forested eco- 
systems: implications for forest management. Ecological Applications 5 (4): 969-977. - doi: $10.2307 / 2269348$

Sabatini FM, Burton JI, Scheller RM, Amatangelo KL, Mladenoff DJ (2013). Functional diversity of ground-layer plant communities in old-growth and managed northern hardwood forests. Applied Vegetation Science 17: 398-407. - doi: 10.1111/avsc.12083

Scheller RM, Mladenoff DJ (2002). Understory species patterns and diversity in old-growth and managed northern hardwood forests. Ecological Applications 12: 1329-1343. - doi: 10.1890/ 1051-0761(2002)012[1329:USPADI]2.0.CO;2

Schlaghamersky J (2000). The saproxylic beetles (Coleoptera) and ants (Formicidae) of Central European hardwood floodplain forests. Folia Facultatis Scientarium Naturalium Universitatis Masarykianae Brunensis, pp. 103.

Sobolewska D, Podolak I, Makowska-Was J (2013). Allium ursinum: botanical, phytochemical and pharmacological overview. Phytochemistry Reviews 14: 81-97. - doi: 10.1007/s11101-0139334-0
Swanson ME, Franklin JF, Beschta RL, Crisafulli CM, Della Sala DA, Hutto RL, Lindenmayer DB, Swanson FJ (2010). The forgotten stage of forest succession: early-successional ecosystems on forest sites. Frontiers in Ecology and the Environment 9 (2): 117-125. - doi: 10.1890/090157 Ter Braak CJF, Wiertz J (1994). On the statistical analysis of vegetation change: a wetland affected by water extraction and soil acidification. Journal of Vegetation Science 5: 361-372. doi: $10.2307 / 3235860$

Vandekerkhove K, De Keersmaeker L, Menke N, Meyer P, Verschelde P (2009). When nature takes over from man: dead wood accumulation in previously managed oak and beech woodlands on North-western and Central Europe. Forest Ecology and Management 258: 425-435. - doi: 10.1016/j.foreco.2009.01.055

Ward V, Tockner K, Schiemer F (1999). Biodiversity of floodplain river ecosystems: ecotones and connectivity. Regulated Rivers: Research and Management 15: 125-139. - doi: 10.1002/(SI CI)1099-1646(199901/06)15:1/3<125::AID-RRR52 3>3.0.CO;2-E
Wright IJ, Reich PB, Westoby M, Ackerly DD, Baruch Z, Bongers F, Cavender-Bares J, Chapin T, Villar R (2004). The worldwide leaf economics spectrum. Nature 428: 821-827. - doi: 10.1038 /nature02403

Wright JS (2002). Plant diversity in tropical forests: a review of mechanisms of species coexistence. Oecologia 130 (1): 1-14. - doi: 10.1007/soo 4420100809

Zapponi L, Minari E, Longo L, Toni I, Mason F, Campanaro A (2014). The habitat trees experiment: using exotic tree species as new microhabitats for the native fauna. iForest 8: 464470. - doi: 10.3832/ifor1281-007

\section{Supplementary Material}

Tab. S1 - List of shade and drought tolerance trait values for overstory and understory vascular species.

Link: Chianucci_1789@supplo01.pdf 